\title{
The dynamics of sprouts generation and colonization by macrofungi of black cherry Prunus serotina Ehrh. eliminated mechanically in the Kampinos National Park
}

\author{
Katarzyna Marciszewska ${ }^{1}$, Andrzej Szczepkowski ${ }^{2}$, Anna Otręba $^{5}$, Lidia Oktaba ${ }^{3}$, \\ Marek Kondras ${ }^{3}$, Piotr Zaniewski ${ }^{1}$, Wojciech Ciurzycki ${ }^{1}$, Rafat Wojtan ${ }^{4}$ \\ ${ }^{1}$ Warsaw University of Life Sciences - SGGW, Faculty of Forestry, Department of Forest Botany, Nowoursynowska 159, \\ 02-776 Warsaw, Poland, phone: +48 22 5938026, e-mail: kmarciszewska@wl.sggw.pl \\ ${ }^{2}$ Warsaw University of Life Sciences - SGGW, Faculty of Forestry, Department of Forest Protection and Ecology, \\ Nowoursynowska 159, 02-776 Warsaw, Poland \\ ${ }^{3}$ Warsaw University of Life Sciences - SGGW, Faculty of Agriculture and Biology, Department of Soil Environment \\ Sciences, Nowoursynowska 159, 02-776 Warsaw, Poland \\ ${ }^{4}$ Warsaw University of Life Sciences - SGGW, Faculty of Forestry, Department of Dendrometry and Forest Productivity, \\ Nowoursynowska 159, 02-776 Warsaw, Poland \\ ${ }^{5}$ Kampinos National Park, Tetmajera 38, 05-080 Izabelin, Poland
}

\section{Abstract}

The experiment conducted in the Kampinos National Park since 2015 is aimed at investigating the relationship between the dynamics of black cherry sprouting response and the type and term of implementation of the mechanical elimination procedure. It also identifies macrofungi colonizing trees undergoing eradication. Three treatments, basal cut-stump, cutting (height: ca. $1 \mathrm{~m}$ ) and girdling, were performed on 4 terms: early and late spring, summer and winter. Each variant was conducted within two plots, and applied to 25 trees, to 600 trees in total. For two consecutive vegetation seasons, sprouts were removed approximately every 8 weeks with the exception of winter-treated trees. Qualitative data were analysed, that is, the number of trees with and without sprouts at subsequent controls, and at the end of the second season, except winter-treated trees. Initially, almost $100 \%$ of the trees cut at the base and cut high responded by sprouting. The share of trees without sprouts gradually increased during the following vegetation season, from $3^{\text {rd }}$ to $5^{\text {th }}$ repetition of the sprouts removal, depending on the variant of experiment. Girdling contributed to a delay in sprouting. The effectiveness of procedures, expressed as share of trees without sprouts at the end of the second vegetation season, ranged widely $(12 \%-84 \%)$, and depended statistically significantly on the date of the treatment. The effectiveness was higher for treatments done in early (average 68\%) and late spring (average 74\%), as compared to those done in summer (average 35\%). Mycological research concerned 600 trees, including those treated in winter, without sprouts removal. Occurrence of 26 taxa of macrofungi was confirmed on $25 \%$ of trees; most of them having wood-decaying properties. Chondrostereum purpureum was most frequent, colonizing $9 \%$ of trees. Impact of plots varying soil moisture on succession and rate of fungi colonization, and on sprouting response dynamics requires further research. 


\section{KeY WORDS}

eradication - girdling, sprouting, stump cutting, invasive plant, macromycetes, soil C:N ratio, wood decay fungi

\section{INTRODUCTION}

The ability to generate sprouts in response to mechanical damage or extremely unfavourable growth conditions is part of life strategy of some woody plants. This property, important from a biological point of view and sometimes used for forest renewal (Del Tredici 2001; Vesk and Westoby 2004), becomes a significant obstacle when there is a need to eliminate trees identified by humans as unwanted. In the forestry experience, clearance of 'unwanted' trees in the course of treatments, such as early or late cleaning, is a long-established procedure (e.g., Johansson 1992; Andrzejczyk and Milewski 2017). In recent decades, the scope of cleaning treatments has expanded and now includes the elimination of trees of foreign origin from forests.

Nowadays, black cherry Prunus serotina Ehrh. ( $\mathrm{Pa}$ dus serotina (Ehrh.) Borkh.), an invasive anthropophyte characterized by a high sprouting capacity, is among the alien species unwanted in the Polish forests (e.g., Marquis 1990; Closset-Kopp et al. 2007; Halarewicz 2012). As the species is wide spread in Europe, including Poland (Vanhellemont 2009; Tokarska-Guzik et al. 2012; Bijak et al. 2014), many activities are undertaken, especially within protected areas, that are aimed at reducing its occurrence (e.g., Najberek and Solarz 2011; Tittenbrun and Radliński 2015). The methods used to eradicate unwanted plants are most often based on field experience and not on the results of extensive research. Starfinger et al. (2003) noted that attempts to remove black cherry undertaken without thorough knowledge and analysis are yet another mistake, just like the prior intentional introduction of this species.

The experiment, launched in 2015 in the Kampinos National Park (later referred to as KPN), consisting of mechanical elimination of black cherry (Otręba et al. 2017) is intended to find answers to the question on how the technique and the time of implementation of the treatment may reduce the sprouting capacity of black cherry. Researches conducted in Belgium and Italy show that among the mechanical methods of black cherry elimination, girdling renders the best results
(Van den Meersschaut and Lust 1997; Annighöfer et al. 2012), just like in the case of black locust in Germany (Böcker and Dirk 2007). After the first growing season of the experiment in the KPN, it was proved that, indeed, stem girdling significantly reduces the sprouting capacity of the trees, expressed in number, length and dry weight of sprouts, as compared to cutting. However, this method is not fully effective, as the majority of trees generated sprouts (Otręba et al. 2017). In turn, cutting stem at a height of approximately $1 \mathrm{~m}$ above the ground as a way to reduce the sprouting capacity of black cherry is applied in practice in several Polish national parks: Bory Tucholskie, Kampinos, Roztocze, Wigry (Namura-Ochalska and Borowa 2015; Krzysztofiak and Krzysztofiak 2015; Tittenbrun and Radliński 2015). The results obtained by us in the KPN have evinced that this procedure reduces the sprouting capacity of black cherry to a small extent, which is statistically significant only in the case of the length of generated sprouts, when compared to the basal cut-stump (Otręba et al. 2017).

Lack of natural enemies is widely considered to be one of the sources of success of invasive species in their new homelands including black cherry (Halarewicz 2012). However, little research has been devoted to the relationship between black cherry and its potential enemies within secondary range. Until today, in Poland, there have been no dedicated studies on macrofungi occurring on the wood of this anthropophyte. The few published mycological data relating to the host species/substrate were usually provided broadly for the genus Prunus or Padus (e.g. Wojewoda 2003; Karasiński et al. 2015). Fungus Chondrostereum purpureum is an exception as it is used in Western Europe for biological elimination of undesirable deciduous species, including black cherry (e.g., Van den Meersschaut and Lust 1997; de Jong 2000; Roy et al. 2010). However, there are known observations, including those in the protection district Rózin of the KPN, where spontaneous occurrence of wood decaying fungi was confirmed (Namura-Ochalska and Borowa 2015). Therefore, in the second season, we expanded our experiment to include research on macrofungi as 
a natural factor, potentially accelerating dying of the eradicated black cherry trees.

In this paper, we present the results of the experiment testing various methods of mechanical elimination of black cherry in the KPN after two growing seasons. The aim of our work is to find answers to the following questions: How long, in spite of the removal of sprouts, do cut or girdled black cherries retain the ability to regenerate? Does the dynamics of black cherry sprouting capacity depend on the type of treatment of mechanical eradication and the time of performing thereof? What macrofungi colonize black cherry that has been deliberately mechanically damaged? Is there a relationship between the type and term of mechanical treatment implemented to eliminate black cherry and the extent of colonization of the trees by macrofungi?

\section{MATERIAL AND METHOdS}

The study assessing the effectiveness of particular methods of mechanical elimination of black cherry was started in the Kampinos Natural Park (KPN) during the 2015 vegetation season. It is run under the form of an experiment in natural conditions and continued in the year 2016. A total of 600 trees from two spatially separated populations (300 trees in each population) were selected for the experiment. At the same time, these two populations form two distinct research areas located within the Laski protection district in the KPN. Sieraków plot is located within division 345 of Sieraków protection district, while Lipków plot is within division 185 of Lipków protection district.

The location of the study area and the characteristics of the sample trees and research plots were presented in the publication summarizing the results of the first season of the study (Otręba et al. 2017). In 2016, the soil research was performed and the characteristics of the plots were extended.

\section{Soil research}

For each research plot, a single soil profile was made and described. The classification of the soils is given in accordance with the Classification of Forest Soils in Poland (Zespół klasyfikacji gleb leśnych 2000) and with the World Reference Base for Soil Resources - WRB (IUSS Working Group WRB 2015).
Laboratory tests of soil samples were carried out using the methods commonly implemented in soil science (Van Reeuwijk 2002). Particle size distribution was determined using the Casagrande method, as modified by Prószyński, and designation to texture classes was made in accordance with the Polish Soil Science Society (2009). Organic carbon (Corg) content was determined with the method of combustion at $900{ }^{\circ} \mathrm{C}$ using carbon analyser Shimadzu 5000A; total nitrogen (Nt) content was determined with the Kjeldahl method using Kjeltec-Tecator analyser; $\mathrm{pH}$ in water and $1 \mathrm{M} \mathrm{KCl}$ were determined with the potentiometric method using soil to solution ratio of 1:2.5; hydrolytic acidity $(\mathrm{Hh})$ was determined using calcium acetate at $\mathrm{pH}=8.2$; base cations $(\mathrm{Ca}, \mathrm{Mg}, \mathrm{K}, \mathrm{Na})$ were extracted in ammonium acetate at $\mathrm{pH}=7$ and identified using ASA Perkin-Elmer 2100 instrument. Trophic Soil Index (SIG) was calculated on the basis of the above-mentioned parameters among others (Brożek et al. 2011).

\section{The study of the dynamics of sprouts generation}

Three types of treatments of mechanical elimination of black cherry were applied: cut-stump at the base, cutting the tree stem at the height of ca. $1 \mathrm{~m}$ above the ground level, and girdling by removal of the bark, phloem and cambium at the width of ca. $20 \mathrm{~cm}$ around the entire circumference of the stem at the height of ca. $1 \mathrm{~m}$ above ground level.

Each of the mechanical treatments that initiated the experiment was carried out at 3 different dates in the 2015 vegetation season, and once during the winter of 2015/2016. At each occasion, the treatment was performed on a group of 50 selected trees, 25 trees in each of the two locations. The procedures were performed on April $8^{\text {th }}$, June $2^{\text {nd }}$, July $29^{\text {th }}$, and February $8^{\text {th }}-10^{\text {th }}$, which correspond to the astronomical: early spring, late spring, summer, and winter respectively. From the phenological perspective, the first date corresponds to the period before blooming, the second - to the period of blooming, the third - to the period of fruit yielding, and the fourth - to the winter rest of trees. A total of 450 trees were subjected to the procedure in the 2015 vegetation season and subsequent 150 trees in the winter of 2015/2016.

Control removals and measurements of generated sprouts were carried out three times in each vegetation season, approximately at 8 -weeks interval after the particular initial treatment, on the following dates: 
1 - June $1^{\text {st }}, 2015,2$ - July $28^{\text {th }}, 2015,3$ - September $20^{\text {th }}, 2015,4-$ June $2^{\text {nd }}$ and $6^{\text {th }}, 2016,5-$ August $16^{\text {th }}$ and $18^{\text {th }}, 2016,6$ - October $4^{\text {th }}, 2016$.

Control removals of generated sprouts at any given instance included only 450 trees, as the sprouts generated from the trees eliminated through the winter treatment were not removed throughout the entire season, and only the length of the 3 strongest sprouts was measured in the field at the time of the last control removal. Apart from that exception, for each tree, the presence or absence of sprouts at the subsequent control dates was recorded. These qualitative data are presented as the number of trees that did and did not generate sprouts, for each type and time of the procedure, and for each plot.

\section{Mycological research}

The list of macrofungi species has been developed based on sporocarps found on black cherry trees within the plots. Collection of sporocarps of macrofungi necessary to identify the species and to estimate the number of sporocarps occurring on individual black cherry plants was done in the second half of October 2016: first, within the plot in Sieraków and approximately 2 weeks later, within the plot in Lipków. For each tree included in the experiment, a list of fungi found on stumps and stems resulting from procedures of mechanical elimination was made. The number of detections of a particular fungi taxon identified on mechanically eliminated trees is synthetically shown as the turnout according to the type of the procedure, the date of implementation thereof, and location of the plot.

In addition, for both research plots, a list of species of fungi found on lying logs and branches, as well as trees, mostly damaged and dead, of black cherry that died due to the circumstances not related to the elimination procedures, was drawn.

The collected material was analysed using methods conventional in fungal taxonomy with implementation of light microscope (Clemeçon 2009). The nomenclature was adopted predominantly after Knudsen and Vesterholt (2012) as well as the MycoBank (www.mycobank.org).

\section{Statistical analysis}

Considering the number of observations and the data structure, it was decided to conduct statistical analysis with nonparametric methods. Inference was done for the significance level set to $\mathrm{p}=0.05$. Friedman's test was used in order to test whether there are statistically significant differences: in the dynamics of sprouts, generation calculated as the number of trees that generated sprouts at the time of the subsequent control dates, and the extent of colonization of these trees by macrofungi depending on the implemented procedures. It allows to examine the occurrence of differences between repeated measures across multiple tests. Wilcoxon test was used in order to assess the significance of the differences for particular pairs of variants of the experiment.

In order to determine which variants of the experiment have similar effectiveness, cluster analysis was performed. The results of the observations for particular variants of the experiment were clustered on the basis of the data regarding the number of trees with sprouts recorded on subsequent control dates. Clustering was carried out by the complete-linkage method (furthest neighbour clustering) for Euclidean distances. The Microsoft Office Excel and Statsoft Statistica 13 packages were used for calculations, analyses and the database generation.

\section{Results}

\section{Properties of the soils within the research plots}

According to the Classification of Forest Soils in Poland (Zespół klasyfikacji gleb leśnych 2000), the soil from the plot in Sieraków was classified to the type Arenosole (Polish), subtype arenosol bielicowany (ARb); while according to the World Reference Base for Soil Resources - WRB (IUSS Working Group WRB 2015), it was classified to Albic Arenosol (Aeolic). The following sequence of horizons was identified: O-AEesin-Bhfe1-Bhfe2-BhfeC-C1-C2-C3-Ab-Bvb. The soil from the plot in Lipków was classified to the type gleba bielicowa (Polish), subtype gleba glejo-bielicowa właściwa (Bgw) głęboko gruntowoglejowa (Zespół klasyfikacji gleb leśnych 2000) and as Gleyic Albic Podzol (according to the WRB classification, IUSS Working Group WRB 2015). The following horizon sequence was identified: O-A-EesBhfe-BhfeGo1-BhfeGo2-BhfeGo3-Gorl-Gor2-Gor3-Gr.

On the basis of the percentage share of particles of specific sizes, the soils within both test plots were allocated to the same particle size group viz. loose sands. Particles of the size $0.10-0.25 \mathrm{~mm}$ constitute the predominant fraction of the soils examined. 
Within the plot in Sieraków, the amount of organic carbon in the soil has the highest level within the O horizon, where it was equal to $40.9 \%$ (Fig.1). The content of this element decreased with the depth: from $0.8 \%$ in the humus horizon to zero in parent material (Fig. 1). Within the Ab horizon of fossil soil, at the depth of 210 $\mathrm{cm}$, the amount of organic carbon increased again to $0.6 \%$. The amount of nitrogen fluctuated similarly, decreasing from $0.800 \%$ in the $\mathrm{O}$ horizon to $0.003 \%$ in parent material, and increased within the Ab horizon to $0.010 \%$ (Fig. 1). The C:N ratio within the humus horizon was 29.1, while in the remaining horizons, it was slightly lower (Fig. 2). The $\mathrm{pH}$ values in water (3.69-4.52), and these of $1 \mathrm{M}$ potassium chloride (3.36-4.11) indicate strongly acidic nature of the soil.

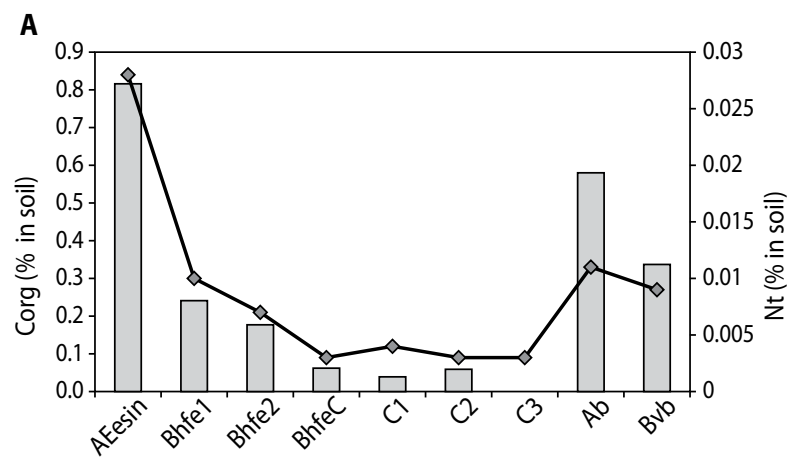

B

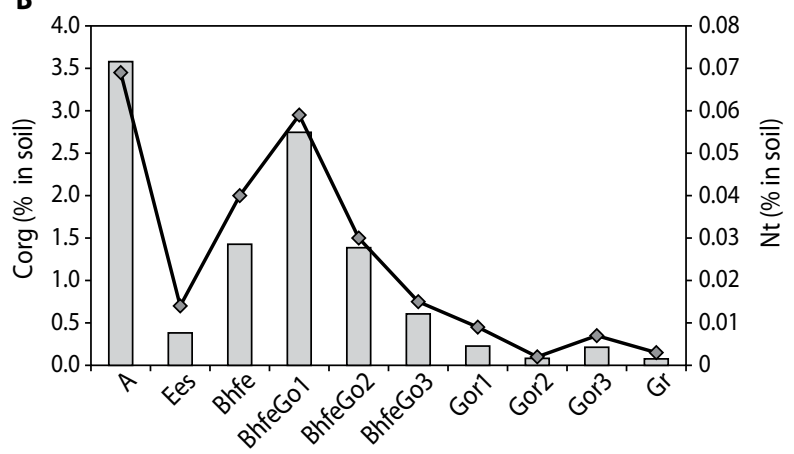

Figure 1. Percentage share of organic carbon and nitrogen in the subsequent soil horizons within the test plots in Sieraków (A) and Lipków (B) in the Kampinos National Park. Corg - organic carbon; $\mathrm{Nt}$ - total nitrogen. The bars represent the organic carbon content, point-to-point graph - total nitrogen content

In the soil, within the plot in Lipków, higher amount of organic carbon was reported as compared to Sieraków (Fig. 1). The amount of this element within the
O horizon equalled $33.3 \%$, while in the humus horizon, it amounted up to $3.6 \%$. The organic carbon content in other horizons was the outcome of podzolization process and, to a lesser extent, also of the ground water impact. As a result of podzolization, the amount of this element in the Ees horizon was lowered. In the illuvial horizon Bhfe, at the depth of 20-30 cm, significant accumulation of organic carbon can be seen, as here its content reached $2.7 \%$. Greater amount of total nitrogen was found in the soil within the test plot in Lipków as well (Fig. 1). This element was distributed throughout the profile similar to carbon. The largest amount of $\mathrm{Nt}$ was observed within the $\mathrm{O}$ horizon $(0.690 \%)$ and among the mineral horizons - within the humus horizon $(0.069 \%)$. The $\mathrm{C}: \mathrm{N}$ ratio for this soil was very high, and in the A horizon, it amounted to 51.9 (Fig. 2). In the other horizons, this ratio was quite varied, but also indicated a significant predominance of organic carbon over nitrogen (Fig. 2).

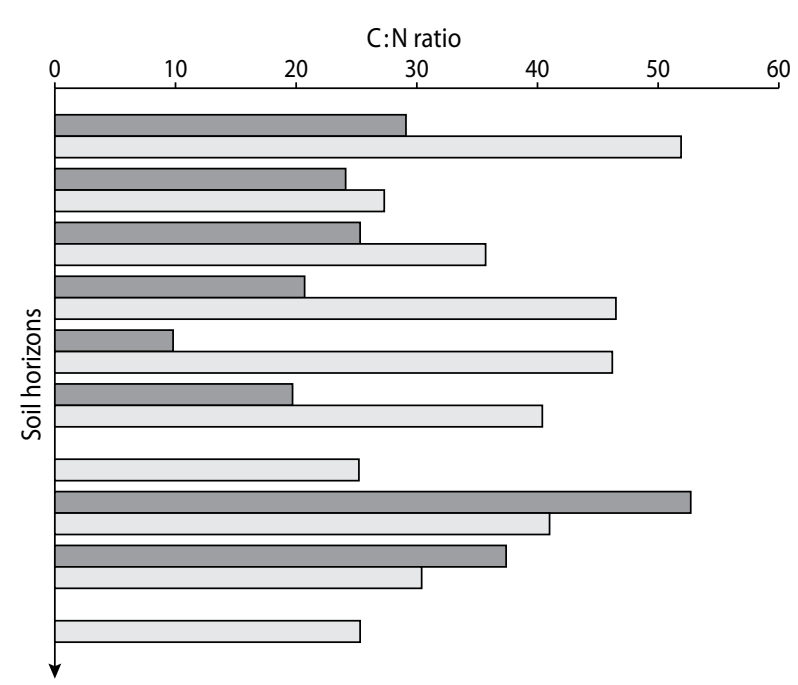

Figure 2. The carbon to nitrogen ratio $(\mathrm{C}: \mathrm{N})$ in the subsequent soil horizons within the test plots in Sieraków and Lipków in the Kampinos National Park. Dark bars - the soil within the plot in Sieraków; light bars - the soil within the plot in Lipków

The $\mathrm{pH}$ of the soil was strongly acidic, and the $\mathrm{pH}$ values in water (3.13-4.67), and these of $1 \mathrm{M}$ potassium chloride (2.78-4.22) were lower when compared with the soil within the plot in Sieraków. Trophic Soil Index (SIG) for the soil in Sieraków is equal to 11, and for the soil in Lipków is equal to 12. 


\section{The dynamics of sprout generation response and assessment of the effectiveness of the mechanical procedures for black cherry elimination}

The analysis of the entire results of the experiment showed that the number of trees generating sprouts between the subsequent controls differed in statistically significant manner (Friedman test: $\mathrm{Chi}^{2}=31.11$; $p<0.0001)$ between the variants of the experiment differentiated when it comes to the location, as well as the type of procedure, and the date of the initial implementation thereof. Cluster analysis was performed in order to determine which variants of the experiment have similar effectiveness (Fig. 3).

The analysis revealed a split into two large groups distinguished on the basis of the date of the initial treatment. A separate group, constituting the left part of the diagram, was formed by all the variants of the experiment; in the case of this group, the initial treat- ment had been performed in summer. However, it has to be noted that two variants of the experiment with the initial treatment done in early spring were within this group as well. The type of procedure turned out to be the next factor differentiating the variants of the experiment within each of the two main groups. The variants in which girdling was used were most similar to each other in terms of sprouting response. The height of cutting and location were the factors clustering results at lower levels. This means that the sprouting response of the trees in the areas varying when it comes to these factors was similar to each other.

The dynamics of black cherry sprouting response is presented as a percentage share of trees with sprouts and without sprouts at subsequent control dates, separately for each of the two locations (Fig. 4 and 5). Regardless of the date of the initial procedure, the trees in almost $100 \%$ responded by immediate generation of sprouts if they were subject to cut-stump at the ground-level and

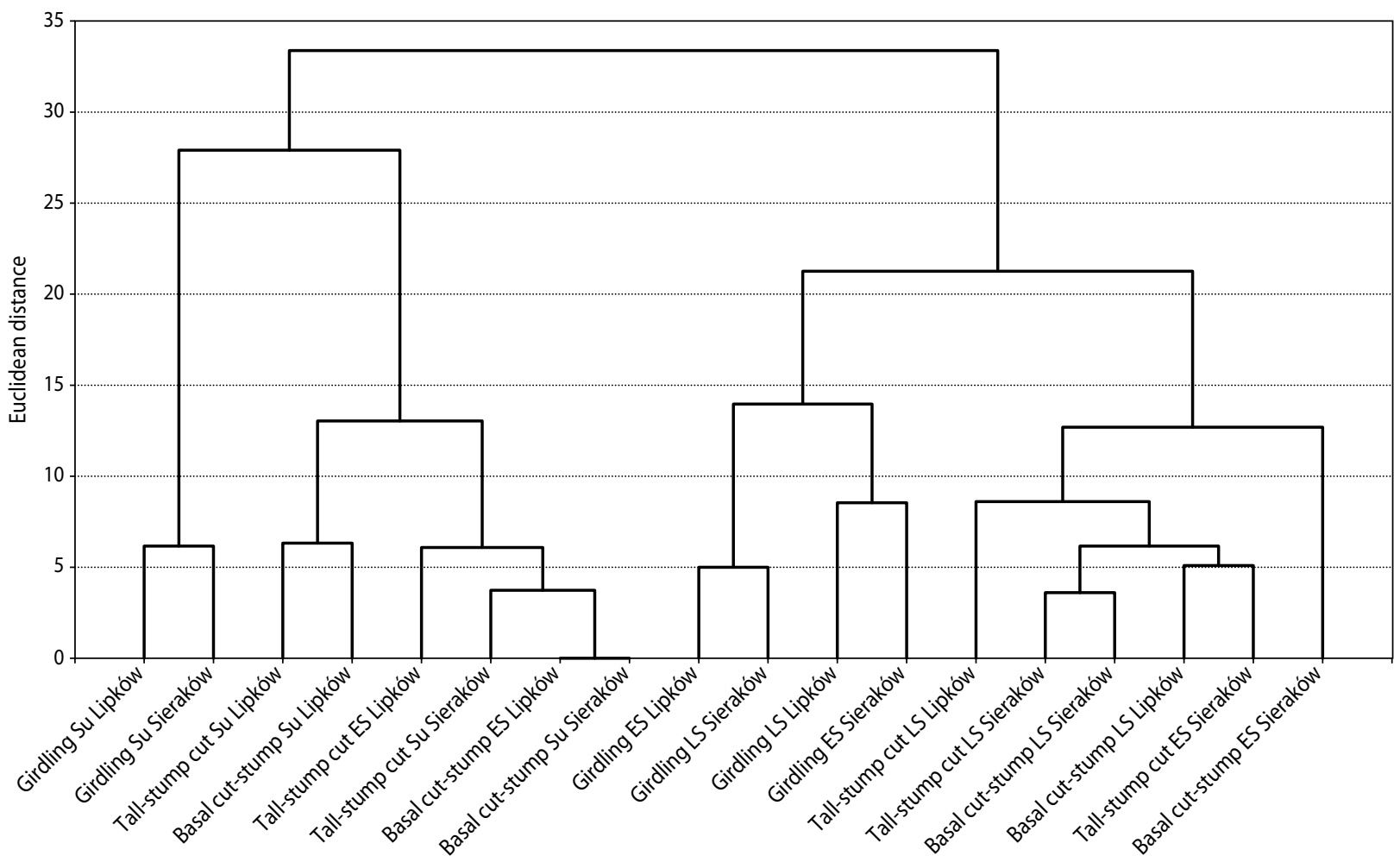

Figure 3. Chart representing clustering of the variants of the experiment varied in terms of the location, the type, and the date of the initial treatment of mechanical elimination of black cherry. Cluster analysis using the complete-linkage method and Euclidean distance. Location of the plots: Lipków, Sieraków; term of the initial treatment: ES - early spring, LS - late spring, $\mathrm{Su}-$ summer. Each variant included 25 trees, 450 in total 


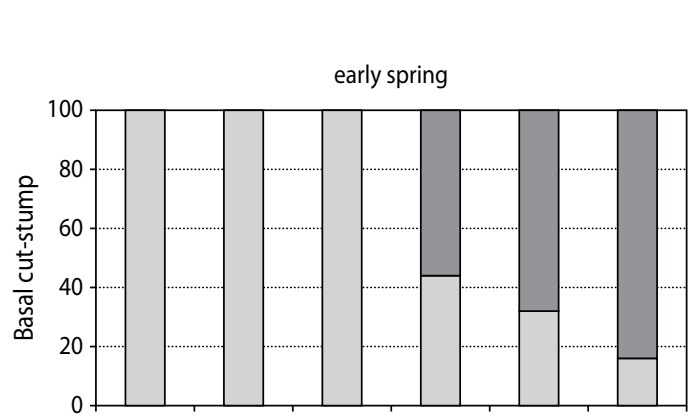

\section{Time of initial treatment}
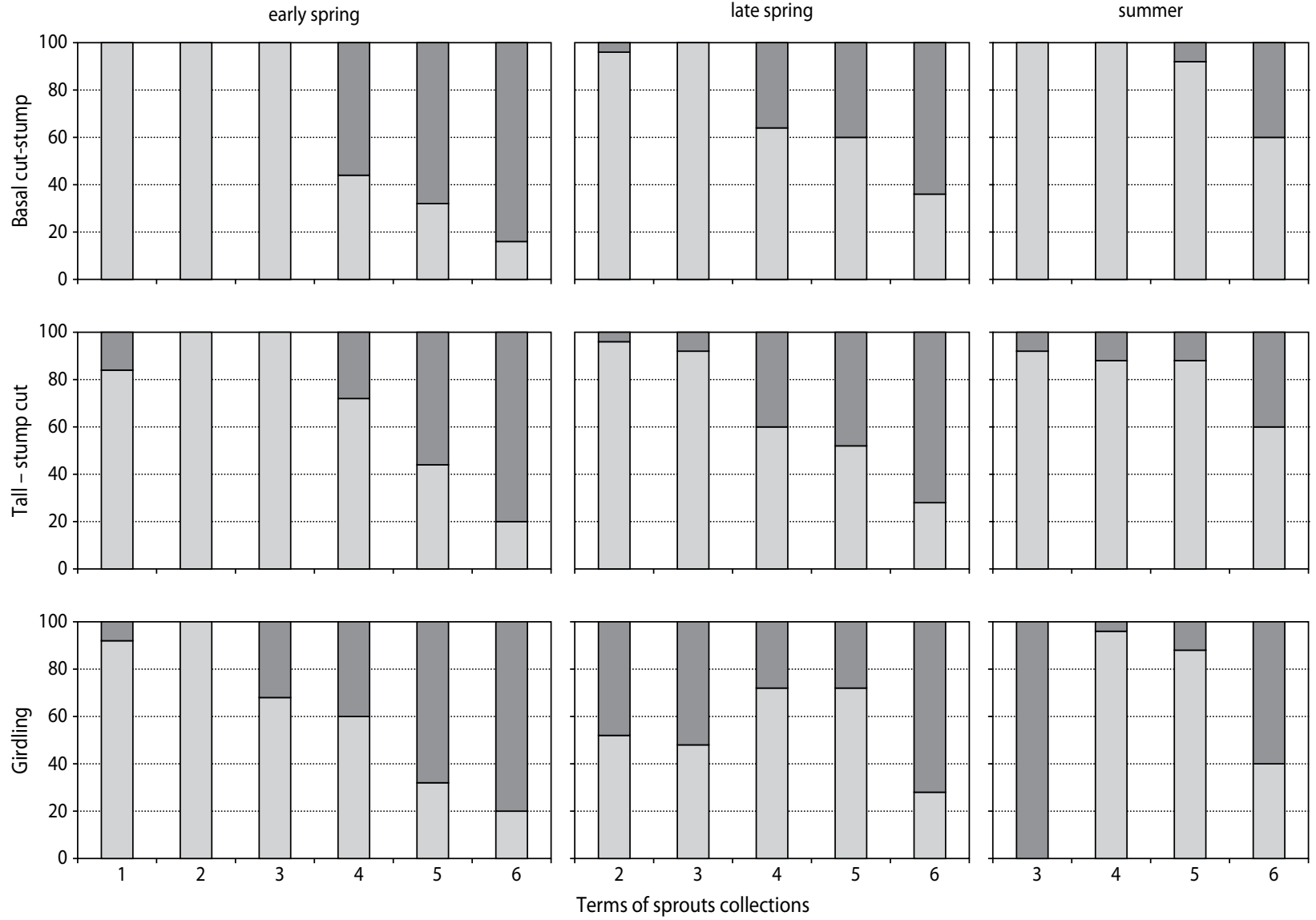

Figure 4. The dynamics of black cherry sprouting response during the two seasons of the experiment at the test plot in Sieraków. Data is displayed as a percentage share. Dark bars - trees without sprouts; light bars - trees with sprouts. Terms of sprouts collections: 1 - June $1^{\text {st }}, 2015,2$ - July $28^{\text {th }}, 2015,3-$ September $20^{\text {th }}, 2015,4-$ June $2^{\text {nd }}$ and $6^{\text {th }}, 2016,5-$ August $16^{\text {th }}$ and $18^{\text {th }}, 2016,6-$ October $4^{\text {th }}, 2016$

cutting at the height of $1 \mathrm{~m}$ above the ground. Progressing decline in the ability to generate sprouts was observed only at subsequent removals of sprouts, and only in the case of some trees. Depending on the variant of the experiment, the share of trees with sprouts gradually decreased starting from 3 to 5 repetition of sprout removal. The loss of sprout generation capacity started faster in the case of trees cut in late spring (by one interval of control removal) than in the case of those cut in early spring. This was observed at both locations and for both heights of cutting.

Different dynamics of black cherry sprouting response was observed in the case of girdled trees, as compared with those subject to cutting (Fig. 4 and 5). First of all, at any date of control, a part of trees was always devoid of sprouts. This is true in the case of the first control removal, as well as the following ones. Secondly, the later the initial procedure was carried out, the more delayed generating sprouts was. In the extreme situation, when the girdling procedure was done in summer, none of the trees generated sprouts in the vegetation season of the treatment, and in the following year sprouts were recorded in the case of every specimen. In the case of the late spring, girdling the maximum share of trees with sprouts was ascertained in the course of the third control removal of sprouts, which had already taken place during the following vegetation season. The only exception from the described sprouting response among the girdled trees was the early spring initial gir- 


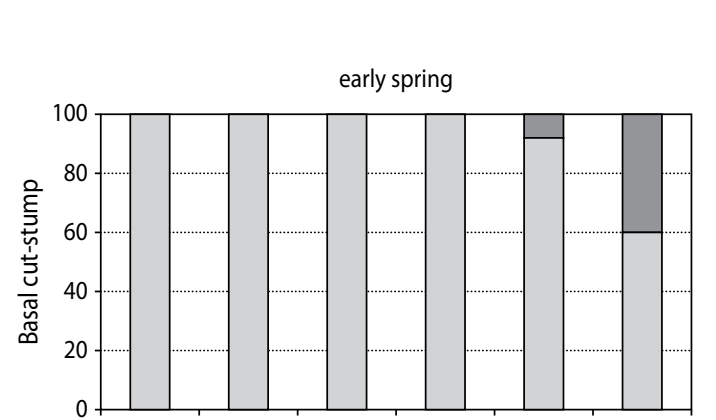

\section{Time of initial treatment}
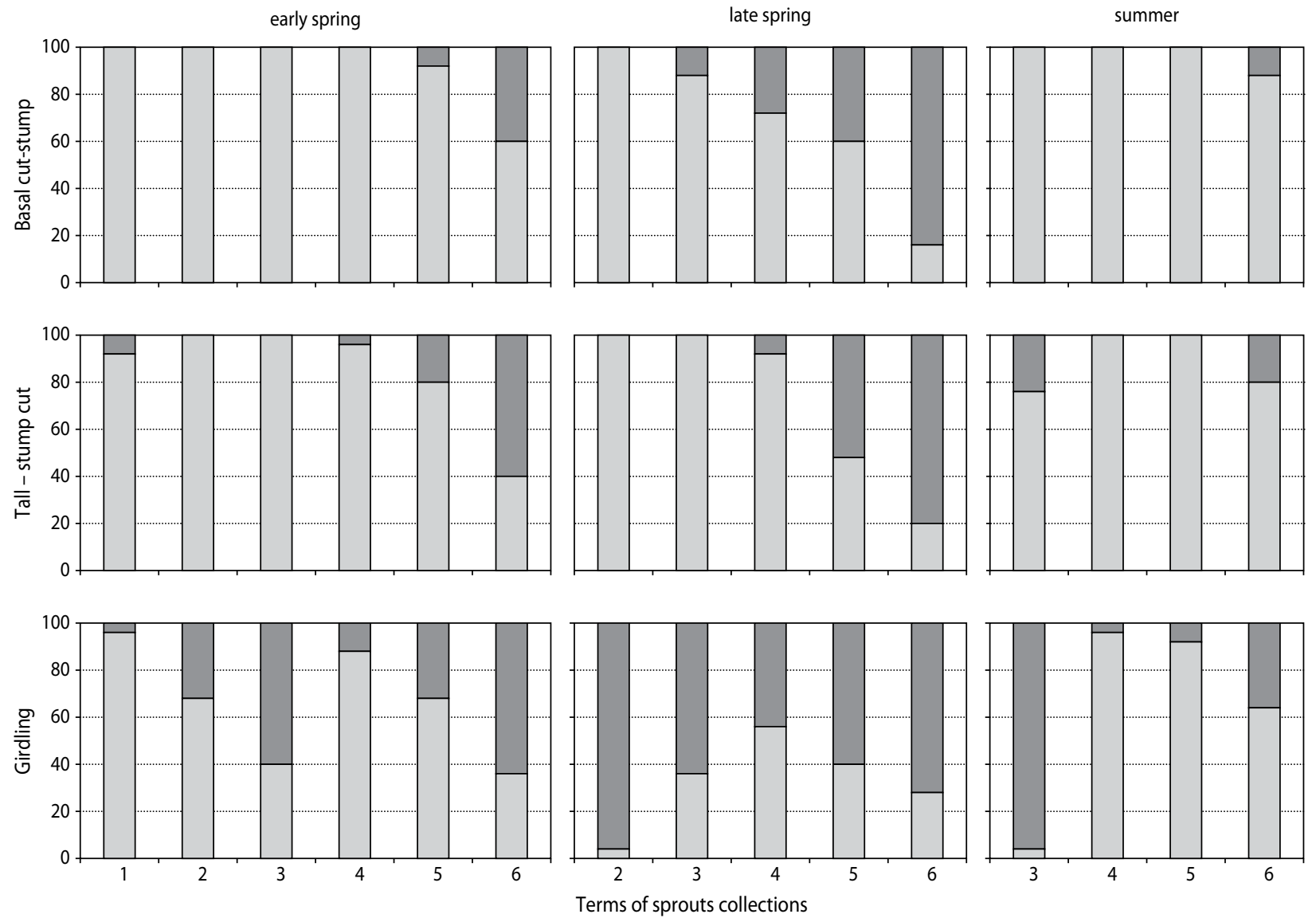

Figure 5. The dynamics of black cherry sprouting response during the two seasons of the experiment at the test plot in Lipków. Data is displayed as a percentage share. Dark bars - trees without sprouts; light bars - trees with sprouts. Terms of sprouts collections: 1 - June $1^{\text {st }}, 2015,2$ - July $28^{\text {th }}, 2015,3$ - September $20^{\text {th }}, 2015,4-$ June $2^{\text {nd }}$ and $6^{\text {th }}, 2016,5-$ August $16^{\text {th }}$ and $18^{\text {th }}$, 2016,6 - October $4^{\text {th }}, 2016$

dling within the plot in Sieraków, one of the six variants of the experiment.

Assessment of the effectiveness of the treatments applied for black cherry elimination was carried out for the individual variants of the experiment on the basis of the percentage share of trees without sprouts at the end of the second vegetation season separately for Sieraków (Fig. 6A) and Lipków plots (Fig. 6B). This share is within a wide range from $12 \%$ to $84 \%$ and depends on the date of the initial procedure in a statistically significant manner (Friedman test: $\mathrm{Chi}^{2}=9.0 ; \mathrm{p}=0.0111$ ). On the basis of the quantitative analysis of the results, it can be concluded that in the case of the procedures carried out in summer, the least number of trees without sprouts was recorded. On an average, this share was equal to
$35 \%$, while for the early spring period, it equalled $68 \%$, and for late spring, it was $74 \%$. Therefore, the procedures carried out in spring should be considered more efficient, while those carried out in summer as the less effective ones.

Differences in the number of trees without sprouts for each type of the procedure (basal cut-stump, tallstump cut, girdling) are not proven to be statistically significant (Friedman test: $\mathrm{Chi}^{2}=1.24 ; \mathrm{p}=0.5385$ ).

Furthermore, no significant difference in the tested value between particular locations was concluded (Wilcoxon test: $Z=1.82 ; p=0.0687$ ). However, it should be noted that in this case, the $p$-value was close to the level of significance $(\alpha=0.05)$, which is generally adopted in statistical analysis. Within the plot in Sieraków 
(Fig. 6A), the initial procedures carried out in early spring were more effective, while in Lipków (Fig. 6B), those carried out in late spring and summer were more effective.
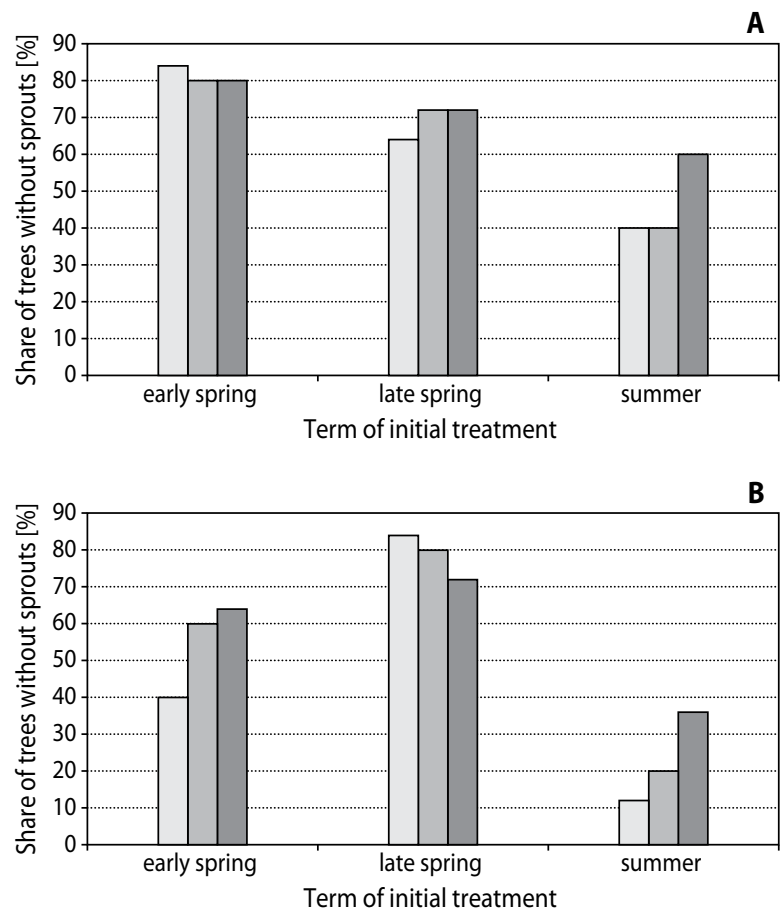

Figure 6. The effectiveness of mechanical procedure to eliminate black cherry expressed as the share of trees without sprouts at the end of the second vegetation season, depending on the type and date of the initial treatment. A - plot in Sieraków; B - plot in Lipków. Light grey bars - basal cut-stump; grey bars - tall-stump cut; dark grey bars - girdling. Each variant included 25 trees, 450 in total on both plots

\section{Colonization by macrofungi of black cherry trees undergoing eradication}

In total, 26 species of macrofungi were detected, including 24 taxa of Basidiomycota and 2 taxa of Ascomycota, all within both the plots, on the trees that were subjected to mechanical elimination (Tab. 1). On the plot in Sieraków, 21 species were found (2 Ascomycota, and 19 Basidiomycota), and within the plot in Lipków, 19 species were found (2 Ascomycota, and 17 Basidiomycota). For both the plots, 13 common species were recorded: Nectria cinnabarina, Basidioradulum radula, Bjerkandera adusta, Chondrostereum purpureum,
Coniophora arida, Exidia plana, Heterobasidion annosum, Hohenbuehelia atrocaerulea, Mycena galericulata, Peniophora cinerea, Phlebia tremellosa, Stereum rugosum, and Trametes ochracea. Exclusively within the plot in Sieraków, 7 taxa were present: Ascocoryne cylichnium, Coprinellus micaceus, Fomitiporia punctata, Gloiothele citrina, Mycena haematopus, Resinicium bicolor, and Vuilleminia coryli, while within the plot in Lipków, only 5 were found: Armillaria ostoyae, Cylindrobasidium evolvens, Ganoderma lipsiense, $\mathrm{Hy}$ pholoma fasciculare, Radulomyces confluens (Tab. 1).

Table 1. List of macrofungi species and their frequency observed on black cherries subject to mechanical elimination within two test plots in the Kampinos National Park

\begin{tabular}{|c|c|c|c|c|}
\hline \multirow[b]{3}{*}{$\stackrel{\Xi}{ \pm}$} & \multirow[b]{3}{*}{ Species } & \multirow{2}{*}{\multicolumn{3}{|c|}{$\frac{\text { Frequency }}{\text { Test plot }}$}} \\
\hline & & & & \\
\hline & & 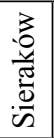 & $\begin{array}{l}3 \\
\frac{2}{2} \\
\frac{2}{2}\end{array}$ & $\stackrel{\pi}{\stackrel{\pi}{0}}$ \\
\hline 1 & 2 & 3 & 4 & 5 \\
\hline \multicolumn{5}{|c|}{ Ascomycota } \\
\hline 1 & Ascocoryne cylichnium (Tul.) Korf & 2 & 1 & 3 \\
\hline 2 & $\begin{array}{l}\text { Nectria cinnabarina (Tode) Fr. anamorph } \\
\text { Tubercularia vulgaris (Tode) }\end{array}$ & 3 & 5 & 8 \\
\hline \multicolumn{5}{|c|}{ Basidiomycota } \\
\hline 3 & Armillaria ostoyae (Romagn.) Herink & & 1 & 1 \\
\hline 4 & Basidioradulum radula (Fr.) Nobles & 2 & 1 & \\
\hline 5 & Bjerkandera adusta (Willd.) P. Karst. & 15 & 8 & 23 \\
\hline 6 & $\begin{array}{l}\text { Chondrostereum purpureum (Pers.) } \\
\text { Pouzar }\end{array}$ & 24 & 29 & 53 \\
\hline 7 & Coniophora arida (Fr.) P. Karst. & 2 & 28 & 30 \\
\hline 8 & $\begin{array}{l}\text { Coprinellus micaceus (Bull.) Vilgalys, } \\
\text { Hopple \& Jacq. Johnson (= Coprinus } \\
\text { micaceus (Bull.) Fr. ) }\end{array}$ & 1 & & 1 \\
\hline 9 & Cylindrobasidium evolvens (Fr.) Jülich & & 18 & 18 \\
\hline 10 & Exidia plana Donk & 1 & 7 & 8 \\
\hline 11 & $\begin{array}{l}\text { Fomitiporia punctata (P. Karst.) Murrill } \\
\text { (= Phellinus punctatus (P. Karst.) Pilát) }\end{array}$ & 1 & & 1 \\
\hline 12 & $\begin{array}{l}\text { Ganoderma lipsiense (Batsch) G.F. Atk. } \\
\text { (= Ganoderma applanatum (Pers.) Pat.) }\end{array}$ & & 1 & 1 \\
\hline 12 & $\begin{array}{l}\text { Gloiothele citrina (Pers.) Ginns } \\
\text { \& G.W. Freeman }\end{array}$ & 1 & & 1 \\
\hline 14 & Heterobasidion annosum (Fr.) Bref. & 2 & 2 & 4 \\
\hline 15 & Hohenbuehelia atrocaerulea (Fr.) Singer & 1 & 2 & 3 \\
\hline
\end{tabular}




\begin{tabular}{|c|c|c|c|c|}
\hline 1 & 2 & 3 & 4 & 5 \\
\hline 16 & $\begin{array}{l}\text { Hypholoma fasciculare (Huds.) } \\
\text { P. Kumm. }\end{array}$ & & 2 & 2 \\
\hline 17 & Mycena galericulata (Scop.) Gray & 2 & 6 & 8 \\
\hline 18 & Mycena haematopus (Pers.) P. Kumm. & 1 & 0 & 1 \\
\hline 19 & Peniophora cinerea (Pers.) Cooke & 3 & 4 & 7 \\
\hline 20 & $\begin{array}{l}\text { Phaeotremella pseudofoliacea } \text { Rea } \\
\text { (= Tremella foliacea } \text { Pers.) }\end{array}$ & 1 & 0 & 1 \\
\hline 21 & $\begin{array}{l}\text { Phlebia tremellosa (Schrad.) Nakasone } \\
\text { \& Burds. }\end{array}$ & 1 & 2 & 3 \\
\hline 22 & Radulomyces confluens (Fr.) M.P. Christ. & & 1 & 1 \\
\hline 23 & $\begin{array}{l}\text { Resinicium bicolor (Alb. \& Schwein.) } \\
\text { Parmasto }\end{array}$ & 1 & & 1 \\
\hline 24 & Stereum rugosum Pers. & 4 & 7 & 11 \\
\hline 25 & $\begin{array}{l}\text { Trametes ochracea (Pers.) Gilb. } \\
\text { \& Ryvarden }\end{array}$ & 1 & 2 & 3 \\
\hline 26 & Vuilleminia coryli Boidin, Lanq. \& Gilles & 1 & & 1 \\
\hline \multicolumn{2}{|r|}{ Number of species on the plot } & 21 & 19 & 26 \\
\hline
\end{tabular}

When taking into account the species of fungi present on wood and bark of trees not subject to the procedures but located within the test plots (Tab. 2), the total number of species of macrofungi increased by 16 and equalled 42, including 3 Ascomycota and 39 Basidiomycota.

Table 2. List of macrofungi species discovered within the test plots in the Kampinos National Park on lying logs, branches and trees of black cherry, which were not observed on the trees subject to the mechanical treatments

\begin{tabular}{|c|c|c|c|}
\hline \multirow[b]{2}{*}{$\stackrel{\Xi}{\Phi}$} & \multirow[b]{2}{*}{ Species } & \multicolumn{2}{|c|}{$\begin{array}{l}\text { Test } \\
\text { Plot }\end{array}$} \\
\hline & & 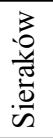 & $\begin{array}{l}\frac{3}{0} \\
\frac{1}{2} \\
\frac{3}{3}\end{array}$ \\
\hline 1 & 2 & 3 & 4 \\
\hline \multicolumn{4}{|c|}{ Ascomycota } \\
\hline 1 & Hypoxylon fuscum (Pers.) Fr. & + & \\
\hline \multicolumn{4}{|c|}{ Basidiomycota } \\
\hline 2 & Byssomerulius corium (Pers.) Parmasto & & + \\
\hline 3 & Coniophora puteana (Schum.) P. Karst. & + & \\
\hline 4 & Daedaleopsis confragosa (Bolton) J. Schrot. & + & + \\
\hline 5 & Datronia mollis (Sommerf.) Donk & & + \\
\hline 6 & Fomes fomentarius (L.) J.J. Kickx & + & + \\
\hline 7 & Hapalopilus nidulans (Fr.) P. Karst. & + & \\
\hline
\end{tabular}

\begin{tabular}{|c|l|c|c|}
\hline 1 & \multicolumn{1}{|c|}{2} & 3 & 4 \\
\hline 8 & Laetiporus sulphureus (Bull.) Murrill & & + \\
\hline 9 & Peniophora incarnata (Pers.) P. Karst. & + & + \\
\hline 10 & Pluteus atricapillus (Batsch) Fayod & + & \\
\hline 11 & Radulomyces molaris (Chaillet) M.P. Christ. & + & \\
\hline 12 & $\begin{array}{l}\text { Schizopora flavipora (Berk. \& M.A. Curtis } \\
\text { ex Cooke) Ryvarden }\end{array}$ & + & + \\
\hline 13 & Skeletocutis nivea (Jungh.) Jean Keller & + & + \\
\hline 14 & Stereum hirsutum (Willd.) Gray & + & \\
\hline 15 & Trametes versicolor (L.) Pilát & + & + \\
\hline 16 & Tremella mesenterica Retz. & + & + \\
\hline
\end{tabular}

+- stands for presence of the taxon.

Chondrostereum purpureum was the most commonly encountered species of fungi present on black cherries, and it was recorded on $9 \%$ of the trees subjected to the procedure (Tab. 1). On both the plots, the turnout of this species was similar: in Sieraków it was recorded 24 times, while in Lipków - 29 times (Tab. 1). This species primarily colonised the stumps resulting from high cutting; occasionally, it was detected on basal cut-stumps and girdled trees (Tab. 3).

Table 3. The most common macrofungi colonizing black cherry trees depending on the type of mechanical treatment within the test plots in the Kampinos National Park

\begin{tabular}{|c|c|c|c|c|c|c|c|c|c|}
\hline \multirow{3}{*}{ Species } & \multicolumn{9}{|c|}{$\begin{array}{l}\text { Number of trees with sporocarps } \\
\text { of fungi }\end{array}$} \\
\hline & \multicolumn{4}{|c|}{ Plot in Sieraków } & \multicolumn{4}{|c|}{ Plot in Lipków } & \multirow{2}{*}{ 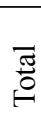 } \\
\hline & $\bigcup_{\infty}$ & $\underset{\bullet}{\circlearrowright}$ & $\circlearrowright$ & 즁 & U & $\underset{\bullet}{\cup}$ & $\circlearrowright$ & 퓽 & \\
\hline $\begin{array}{l}\text { Chondrostereum } \\
\text { purpureum }\end{array}$ & 3 & 21 & & 24 & 1 & 27 & 1 & 29 & 53 \\
\hline Coniophora arida & & & 2 & 2 & 12 & 6 & 10 & 28 & 30 \\
\hline $\begin{array}{l}\text { Bjerkandera } \\
\text { adusta }\end{array}$ & 3 & 12 & & 15 & 3 & 5 & & 8 & 23 \\
\hline $\begin{array}{l}\text { Cylindrobasidium } \\
\text { evolvens }\end{array}$ & & & & & & 2 & 16 & 18 & 18 \\
\hline Stereum rugosum & 1 & 2 & 1 & 4 & 1 & 2 & 4 & 7 & 11 \\
\hline
\end{tabular}

$\mathrm{BC}$ - basal cut-stump, TC - tall-stump cut, $\mathrm{G}$ - girdling.

The other species of macrofungi with a significant number of turnout include: Coniophora arida (30), Bjerkandera adusta (23), Cylindrobasidium evolvens (18), and Stereum rugosum (11) (Tab. 1). The occurrence of the remaining species did not exceed 10 
(Tab. 1). C. arida and S. rugosum were much more often recorded within the plot in Lipków, where $C$. evolvens was also exclusively present. On the contrary, $B$. adusta was almost twice more frequently present within the plot in Sieraków, as compared to the one in Lipków. C. arida preferred girdled trees and those treated with basal cut-stump (Tab. 3). C. evolvens dominated on girdled trees on the wood, in the place where girdling was done. B. adusta colonized stumps (usually the tall ones), but it was not recorded on the girdled trees (Tab. 3).

Sporocarps of fungi were found on 157 out of 600 black cherry trees subject to mechanical elimination, which constitutes slightly more than $25 \%$ of all the specimens (Tab. 4). Nearly twice as many black cherries with sporocarps of fungi were observed within the plot in Lipków than within the one in Sieraków, and this difference is statistically significant (Wilcoxon test: $\mathrm{Z}=2.7456 ; \mathrm{p}=0.0060$ ).

Table 4. Occurrence of macrofungi sporocarps on black cherries depending on the type and timing of mechanical treatment within the test plots in the Kampinos National Park

\begin{tabular}{|c|c|c|c|c|c|c|c|c|c|c|}
\hline \multirow{4}{*}{$\begin{array}{c}\text { Type } \\
\text { of } \\
\text { treatment }\end{array}$} & \multicolumn{10}{|c|}{ Number of trees with sporocarps of fungi } \\
\hline & \multicolumn{5}{|c|}{ plot in Sieraków } & \multicolumn{5}{|c|}{ plot in Lipków } \\
\hline & \multicolumn{10}{|c|}{ Date of treatment } \\
\hline & 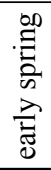 & 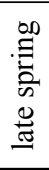 & $\begin{array}{l}\dot{\bar{\Xi}} \\
\dot{\Xi} \\
\stackrel{\Xi}{\Xi}\end{array}$ & 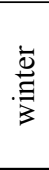 & స్తే & 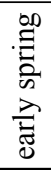 & 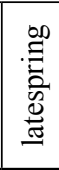 & 离 & 离 & 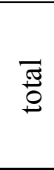 \\
\hline $\begin{array}{l}\text { Basal cut- } \\
\text { stump }\end{array}$ & 4 & 2 & 3 & 2 & 11 & 2 & 9 & 5 & 5 & 21 \\
\hline $\begin{array}{l}\text { Tall-stump } \\
\text { cut }\end{array}$ & 14 & 7 & 7 & 5 & 33 & 19 & 10 & 5 & 8 & 42 \\
\hline Girdling & 2 & 3 & 3 & 4 & 12 & 5 & 11 & 6 & 16 & 38 \\
\hline Total & 20 & 12 & 13 & 11 & 56 & 26 & 30 & 16 & 29 & 101 \\
\hline
\end{tabular}

The highest number of black cherry stumps with sporocarps of fungi was confirmed for the high cutstump, the lowest - for basal cut-stump. The differences in the number of trees colonized by fungi for particular type of procedure were found to be statistically significant (Friedman test: $\mathrm{Chi}^{2}=7.8 ; \mathrm{p}=0.0202$ ). The comparison, made using Wilcoxon test, for each pair of the variants of the experiment showed the existence of statistically significant differences in the number of trees colonized by fungi only between the basal cut-stump and the high cut-stump $(Z=1.6903, p=0.0910)$. Statistically significant differences in the number of trees colonized by fungi were attested neither between the girdled trees and those treated with basal cut-stump $(\mathrm{Z}=1.1202, \mathrm{p}=0.2626$ ), nor between the girdled trees and those treated with high cut-stump $(Z=2.3664$, $\mathrm{p}=0.0180$ ).

The highest number of trees with sporocarps of fungi was confirmed in the case of the initial treatment being done in early spring and winter, smaller when the treatment was done in late spring, and the least number of colonized trees was recorded in the case of the procedure being done in summer (Tab. 4). However, the results of Friedman test indicated that the date of the initial procedure had no statistically significant impact on the number of trees colonized by macrofungi $\left(\mathrm{Chi}^{2}=0.48 ; \mathrm{p}=0.9228\right)$.

\section{Discussion}

\section{Differentiation of the soil properties within the test plots}

The differences in the properties of soils within the test plots in Sieraków and Lipków have their origin primarily in the genesis of these soils and in the soil moisture content. Both, Arenosols found within the plot in Sieraków, and Podzols found within the plot in Lipków, are derived from poor mineral parent materials. The first are derived from sands of various origins. They retain very little water, which determines dry and fresh habitat types of forest (Brożek and Zwydak 2010). Their fertility depends on the water conditions and origins of sands (Zespół Klasyfikacji Gleb Leśnych 2000). Podzols, found within the plot in Lipków, in the Polish lowland are derived mainly from aeolian sands. In Lipków site, the soil was additionally subject to groundwater influence, which resulted in the development of a subtype Gleyic Albic Podzol. As a result of high moisture content and acidic environment, the processes of organic matter decomposition in such soils are inhibited. Typically, this leads to the accumulation of mor-humus (ectohumus) on soil surface with a thickness of up to several centimetres (Zespół Klasyfikacji Gleb Leśnych 2000). In this case, however, there was no significant accumulation of 
ectohumus, but the accumulation of the main components thereof, that is, carbon and nitrogen, within the mineral layers. When comparing the properties of the soils within both the test plots, several times higher content of organic carbon and total nitrogen can be stated for the site in Lipków as compared with Albic Arenosol in Sieraków. In both the cases, Podzolization process was present, however, in the case of the plot in Sieraków it was in its initial stage. The amount of carbon and nitrogen in both Lipków and Sieraków are characteristic of and found in these types of soils. However, relatively high C:N ratio of up to 29.1 within the humus horizon of Albic Arenosol, and 51.9 within the humus horizon of Gleyic Podzol in Lipków indicates a significant deficiency of nitrogen and aberrant biological activity in both the soils.

In Gleyic Podzols examined by Konecka-Betley et al. (2002) in the Kampinos National Park, similar amounts of organic carbon were observed but with several times higher nitrogen content. The researches show that black cherry changes the circulation of nitrogen, phosphorus and carbon in the ecosystems in which it occurs (Halarewicz and Pruchniewicz 2015; Aerts et al. 2017). The species uses nitrogen and other nutrients from the soil more efficiently than native species. According to Dassonville et al. (2008), the impact of black cherry on the chemical properties of soil depends on the trophy of the habitat. Positive impact of enriching soil with nutrients was observed at sites originally poor in nutrients, while negative one in the areas originally rich in nutrients. Aerts et al. (2017) consider this species to have an overall adverse impact on the environment. The $\mathrm{pH}$ values indicate a strongly acidic nature of both the soils, but on an average, in the Gleyic Albic Podzol, the $\mathrm{pH}$ was half a unit lower as compared with the Albic Arenosol. Chabrerie et al. (2008) points out to the acidification of soil in the presence of $P$. serotina, but they expressed the view that this is rather the characteristic of the habitat that causes invasion of black cherry, and not the result of such an invasion.

Synthetic index evaluating soil fertility, that is, the Trophic Soil Index (SIG), in the case of both the soils was within the range of 7 and 13, thus indicating the dystrophic nature of both habitats. According to the soil nature, both the habitats were rated as coniferous forests (State Forests National Forest Holding 2011). How- ever, the undergrowth vegetation as well as stand indicate the habitat to be of mixed coniferous forest type (Otręba et al. 2017). The existence of this inconsistency between the vegetation and the Trophic Soil Index (SIG) may indirectly support the opinion expressed by some authors of a modifying influence of black cherry on soil properties.

\section{The dynamics of black cherry sprouting response to the mechanical elimination}

The two years of experimental elimination of black cherries with mechanical procedures confirmed a high ability of this species to generate sprouts, which is known from the literature of the subject (e.g., Annighöfer et al. 2012; Halarewicz 2012). For the procedures initially carried out in early and late spring, lack of sprouts in at least $60 \%$ of trees (Fig. 4, 5) was confirmed for the majority of the variants of the experiment only at the fifth repetition of control removal of sprouts. The effectiveness of the treatments carried out at two dates in spring, expressed as the share of trees without sprouts, was achieved at the end of the second vegetation season (at $5^{\text {th }}$ or $6^{\text {th }}$ control removal of sprouts) ranged between $40 \%$ and $84 \%$, depending on the variant of the experiment (Fig. 6). In the case of the procedures carried out in summer, with additional 4 control removals, the effectiveness was significantly lower and ranged between $12 \%$ and $60 \%$. A similarly wide range of mortality of black cherry subject to mechanical procedures, although with slightly lower values $(11 \%-74 \%)$, was obtained in the course of an experiment in Belgium. Treatments similar to ours were implemented there (cutting at the height of $0.5-1 \mathrm{~m}$ and girdling) and they were initiated at three dates. However, fewer repetitions of sprouts removals were done, that is, one or two (Van den Meersschaut and Lust 1997). Therefore, it is possible that in practice, one might limit the number of repeated removals of sprouts to two during a vegetation season, and the effect will remain similar. The results obtained showed that when using the mechanical methods of black cherry elimination consisting of cutting or girdling, one has to take into consideration the sprouting response of the trees. Only regular removal of generated sprouts done in the following years may contribute to the death of trees, which entails high labour intensity 
and costs, and, in reality, is not possible to implement on extensive areas.

Both the dynamics of the sprouting response and the effectiveness of treatments obtained at the end of the second vegetation season, differed significantly depending on the variant of the procedure. The date of carrying out the initial mechanical treatment turned out to be the factor most important in the cluster analysis (Fig. 3), which took into account the sprouting response to the treatment performed at various dates. Moreover, this factor proved to be statistically significant when the effectiveness of eradication after two vegetation seasons was compared. The trees, whose elimination started in the summer of 2015 in the following year generated abundant sprouts, and only in the course of the last, that is, the fourth control removal of sprouts was it noted that some of the trees did not generate new sprouts. Also, in the experiment in Belgium, significantly lower effectiveness of the treatments was reported for the ones that had been carried out in summer (Van den Meersschaut and Lust 1997). However, it cannot be excluded that lower effectiveness obtained by us for the procedures performed at this date is affected by lower number of repetitions of control removals of sprouts, as compared to the procedures done in spring. Therefore, it seems that at this stage of the experiment, one cannot draw any definitive conclusions as to the lower effectiveness of the summer treatments. The answer might be obtained only in the next vegetation season. For silver birch, different impact of the date of treatment on sprouting was obtained by Johansson (1992) as well as by Andrzejczyk and Milewski (2017). For the given conditions, in both Sweden and central Poland, the number and size of sprouts generated by silver birch was the lowest in the case of treatments done in summer.

Comparable effectiveness of treatments obtained for the early and late spring, initial procedures favoured the latter due to the possibility of reducing the number of repeated control removals by one. Also, Van den Meersschaut and Lust (1997) recorded the highest mortality rate for the variant of the experiment initiated in late spring and consisting of girdling among the tested dates and types of mechanical elimination.

In our experiment, girdling did not affect the effectiveness of the final elimination but modified the dynamics of sprouting response. Deferred sprouting of girdled trees seems to be associated with the preserva- tion of crown-regenerating capacity of trees during the first vegetation season, which was described by us in the summary of the results obtained in the first season (Otręba et al. 2017). The delayed generation of sprouts and their absence in a substantial part of trees during the first repetition of control removals of sprouts entails lower labour intensity of additional treatments. However, it must be remembered that carrying out girdling requires more time and diligence than cutting down trees, as pointed out by practitioners (Tittenbrun and Radliński 2015). Our results do not indicate the benefits of girdling as compared to the treatment based on cutting down the stems as unambiguously as the ones from Belgium and Italy (Van den Meersschaut and Lust 1997; Annighöfer 2012).

The height at which stems are cut affects neither the course of the sprouting response of trees, nor the final effectiveness of the treatments after the second vegetation season expressed by the number of trees with sprouts. Significantly higher rate of colonization by macrofungi on black cherries treated with tall-stump cutting did not result in higher mortality rate of these trees in the second year of the experiment. Jobidon (1997) as well as Andrzejczyk and Milewski (2017) obtained an opposite effect of high cutting, that is, increased sprout generation in the case of young specimens of: Acer spicatum (mountain maple), Betula papyrifera (paper birch), Prunus pensylvanica (pin cherry), and Betula pendula (silver birch).

Despite the identified differences in the type and the properties of soils (Fig. 1, 2), the sprouting response of black cherry differ only to a small extent depending on the location of the study. The effectiveness of the procedures in the variants of the experiment initiated in late spring was higher within the plot in Lipków, while for the other two dates it was higher in Sieraków; but, nevertheless, these differences were below the threshold of statistical significance. Still, certain variability was attested in the effectiveness of the procedures associated with location, and therefore, the characteristics of the habitat.

\section{Colonization by macrofungi on mechanically eliminated black cherry trees}

All the macrofungi species identified in the course of the research had been previously observed in the KPN (Karasiński et al. 2015). However, black cherry was 
not mentioned as their host/substrate. Only in respect to a few species of fungi genus, Prunus was indicated as their host/substrate After taking into account the species present on the wood and bark of trees not subjected to the procedures but located within the research plots, the total number of macrofungi species equalled 42, including 3 Ascomycota and 39 Basidiomycota. A vast majority of them (at least 31) are the species known for their wood-decaying properties. Dominant are the species (27) causing white rot of wood (e.g., Armillaria ostoyae, Bjerkandera adusta, Chondrostereum purpureum, Cylindrobasidium evolvens, Fomes fomentarius, Stereum rugosum), three species cause brown rot (Coniophora arida, C. puteana, Laetiporus sulphureus), and one species is responsible for white pocket rot (Heterobasidion annosum). Considering the fact that mycological observations were carried out only once, it should be expected that the continuation of the research in the following years will bring an extension of the list of macrofungi species, for which black cherry is a substrate or host.

Within both the test plots, the number of species and the composition of mycobiota were similar, while the extent of colonization of the eliminated trees by fungi was definitely higher within the plot in Lipków. The source of this variability may be in the habitat factors such as higher water content in the soil in Lipków. The soil there is gleyic in nature and remains under strong influence of groundwater. This can lead to a higher and more stable water content in the fungi substrate formed by stumps and trunks of black cherry, and consequently to its faster colonization. However, it cannot be excluded that the ca. two-week time offset of the observations could have some effect on the results obtained. In Lipków, the observations were conducted during a period more favourable for the development of sporocarps of fungi (after a more humid period preceding the observations), and also, they were done a bit later than in Sieraków. Therefore the time for production of sporocarps was also longer and a higher number of them could have been produced.

In the first period, that is, from $7^{\text {th }}$ to $18^{\text {th }}$ month after carrying out the procedure of mechanical elimination of trees, a set of five species of macrofungi widely spread in the world and were responsible for white rot of wood dominated on the wood and bark of black cherries. These were: Chondrostereum purpureum, Coni- ophora arida, Bjerkandera adusta, Cylindrobasidium evolvens and Stereum rugosum.

Among them, the most often recorded species was C. purpureum, which colonized $9 \%$ of all the trees subject to the experiment, and within the group of trees colonized by fungi, it was present on $34 \%$ of trunks. It is a saprotroph, but it also grows as a parasite. It infects live trees, for example cultivated fruit ones and wild ones, causing bark necrosis (killing bark and cambium), and silver-leaf disease (de Jong et al. 1990; Domański 1991; Butin 1995; de Jong 2000; Agrios 2005; Bailey and Mupondwa 2006). It is used for production of bioherbicide used to prevent the generation of sprouts in deciduous trees, among them Prunus serotina (i.e., Gosselin et al. 1999; de Jong 2000; Becker et al. 2005; Roy et al. 2010). Towards the end of $1980 \mathrm{~s}$, it was found that after applying suspension containing mycelium of $C$. purpureum on cut stumps of black cherry, close to $90 \%$ of them died (Scheepens and Hoogerbrugge 1989). Slightly worse, but still satisfactory outcome (mortality rate of black cherry equal to $60 \%$ ) was obtained in the course of the experiment conducted in Belgium (Van den Meersschaut and Lust 1997). In both cases, high efficiency of using low concentration of mycelium in suspension was confirmed and there was no correlation found between the effectiveness of the treatment and date of its implementation (spring, autumn). Researches on the use of mycelium of C. purpureum to counteract generation of sprouts in various species of deciduous trees have been in progress and have provided new results; for example, in Canada, the mortality rate of cut down red alder (Alnus rubra) in the first year was equal to $92 \%$ (Becker et al. 2005).

Bjerkandera adusta was recorded on $6 \%$ of trees, and among the colonized trees, it was present on about $15 \%$ of trunks. It is occasionally a facultative parasite on live trees (damaged and significantly weakened), though more often, it is encountered as saprobiont, similar to Coniophora arida (Ginns 1982; Butin 1995). This latter species colonized $5 \%$ of all the trees and $19.1 \%$ of the trees, which were colonized by fungi.

Cylindrobasidium evolvens was present on 3\% of all trees subject to the elimination procedure and on $11.4 \%$ of the trees colonized by fungi, however, only within the plot in Lipków. This fungus is considered to be one of the first species appearing on dead wood, of- 
ten on dead branches still hanging on trees (Domański 1988; Butin 1995).

Stereum rugosum was found on only about $2 \%$ of the trees subject to the experiment, but it amounted to $7 \%$ in the group of trees colonized by fungi. It grows as a saprotroph and wound parasite causing local bark necrosis leading to the development of bark cancer on stems of deciduous trees (Domański 1991; Butin 1995).

Additionally, the not-very-common presence, of some species of fungi, such as Laetiporus sulphureus and Fomes fomentarius, well-known for their ability to decompose wood and identified as dangerous pathogens was confirmed on black cherry (Butin 1995; Ryvarden and Melo 2014; Sierota and Szczepkowski 2014). Moreover, two dangerous species of root pathogens: Armillaria ostoyae and Heterobasidion annosum were recorded. In Poland, black cherry has probably not been mentioned earlier as a host for the two last mentioned species (Źółciak 2005).

The procedure of tall-stump cutting provided the most favourable conditions for the occurrence of sporocarps of fungi, while the date of the initial treatment did not prove to be statistically significant. However, certain tendencies can be noticed: within the test plot in Sieraków, during the last repetition of control, removal the highest number of trees without sprouts had been subjected to the treatment in early spring. Also, in this set, the number of trees colonized by fungi was the highest. In turn, within the plot in Lipków, the highest number of trees without sprouts was among those subject to the treatment in late spring, and also, in this set, the number of trees colonized by fungi was the highest.

Undoubtedly, the spontaneous colonization of black cherry stumps by macrofungi that was observed in our experiment can be considered as a proof of development of a group of natural enemies of this invasive species in its new homeland. However, determination of the impact the fungi have on accelerating the death of eliminated trees, and what conditions of the procedure implemented are conducive to the colonization by fungi requires further research, including the continuation of this experiment in the following years.

\section{Conclusions}

The two years of the experimental eradication of black cherry in the KPN by implementing mechanical methods have confirmed a high potential of this species to generate sprouts, which is known from the literature of the subject. Moreover, it allowed a more detailed characteristic of the sprouting response in respect to the type and time of the applied method. Our mycological studies in turn have provided the first data in Poland on the occurrence of macrofungi for which black cherry is either substrate or host in its secondary range. Their properties and relationship with type and time of applied mechanical treatment are likely to be the first reports for Poland as well. On the basis of all the results of the research, several statements and conclusions can be drawn, as mentioned below:

1. Initially, almost $100 \%$ of the trees cut at the base and those treated with high-stump cutting responded by generating sprouts. The share of trees without sprouts began to gradually increase in the following vegetation season, starting from $3^{\text {rd }}$ to $5^{\text {th }}$ repetition of sprouts removal, depending on the variant of the experiment. Girdling contributed to the delay in time (postponement) of sprouting response of the trees.

2. The effectiveness of the procedures carried out on the two dates in spring, expressed as the share of trees without sprouts at the end of the second vegetation season of the experiment, ranged from $40 \%$ to $84 \%$, depending on the variant. In the case of treatments carried out in summer, the efficiency was significantly lower and ranged between $12 \%$ and $60 \%$.

3. The date of the implementation of the procedure turned out to be the most important factor differentiating the sprouting response. Moreover, it proved to be statistically significant when comparing the effectiveness of the mechanical elimination of black cherry after two vegetation seasons. However, it seems that at the present stage of the experiment, definitive conclusions as to the lower effectiveness of the summer treatments cannot be formulated.

4. The differences in the effectiveness of the procedures, depending on their type: basal stump-cut, high-stump cut and girdling, were minor and statistically not significant. 
5. The total number of species of macrofungi recorded on the trees growing within the test plots consisted of 3 species of Ascomycota and 39 species of $\mathrm{Ba}-$ sidiomycota.

6. After two seasons of the experiment, ca. $25 \%$ of the eliminated trees were colonized by a total of 26 species of macrofungi: 2 Ascomycota and $24 \mathrm{Ba}-$ sidiomycota.

7. Chondrosterum purpureum was most commonly recorded, as it colonized $9 \%$ of all the trees subject to the experiment. Within the set of trees colonized by fungi, it was present on $34 \%$ of trunks. There were four additional species: Coniophora arida, Bjerkandera adusta, Cylindrobasidium evolvens and Stereum rugosum in the group of the more-often-appearing fungi, though they had a much lower turnout.

8. The majority of recorded marcofungi are species known for their wood-decaying properties. Most of them are responsible for white rot of wood.

9. The treatment consisting of tall-stump cutting provided the most favourable conditions for fungi colonization. The impact of the date of treatment proved not to be statistically significant, which does not coincide with the results obtained for the effectiveness of the mechanical treatments of black cherry elimination. Therefore, at this stage of the experiment, no relationship between the presence of macrofungi and dying out of trees has been determined.

\section{ACKNOWLedgments}

We would like to express our greatest gratitude to Mrs. Anna Andrzejewska of the Kampinos National Park for running the formal aspect of the project. We are also grateful to Mr. Michał Główka for his reliable help in the fieldwork.

Research funded by the forestry fund of the State Forests National Forest Holding under contract No. EZ.0290.1.28.2016.

\section{References}

Bailey, K.L, Mupondwa, E.K. 2006. Developing microbial weed control products: commercial, biological and technological considerations. In: Handbook of Sustainable Weed Management (eds.: H.P. Singh, D.R. Batish, R.K. Kohli), The Haworth Press, Binghamton, NY, 431-473.

Becker, E., Shamoun, S.F., Hintz, W.E. 2005. Efficacy and environmental fate of Chondrostereum purpureum used as a biological control for red alder (Alnus rubra). Biological Control, 33, 269-277.

Bijak, Sz., Czajkowski, M., Ludwisiak, L. 2014. Occurrence of black cherry (Prunus serotina Ehrh.) in the State Forests in Poland. Leśne Prace Badawcze (Forest Research Papers), 75 (4), 359-365.

Böcker, R., Dirk, M. 2007. Ringelversuch bei Robinia pseudoacacia L. - erste Ergebnisse und Ausblick. Berichte des Institutes für LandschaftsPflanzenökologie Universität Hohenheim, 14/15/16, 127-142.

Brożek, S., Zwydak, M. 2010. Atlas of forest soils in Poland (in Polish). CILP, Warszawa, Poland.

Brożek, S., Zwydak, M., Lasota, J., Różański, W. 2011. Methodological assumptions on the relationship between soil and plant communities in forests (in Polish). Roczniki Gleboznawcze - Soil Science Annual, 62 (4), 16-38.

Butin, H. 1995. Tree diseases and disorders. Oxford University Press, Oxford, England.

Chabrerie, O., Verheyen, K., Saguez, R., Decocq, G. 2008. Disentangling relationships between habitat conditions, disturbance history, plant diversity and American black cherry (Prunus serotina Ehrh.) invasion in a European temperate forest. Diversity and Distributions, 14, 204-212.

Clemençon, H. 2009. Methods for working with macrofungi. Laboratory cultivation and preparation of larger fungi for light microscopy. IHW-Verlag, Eching, Germany.

Closset-Kopp, D., Chabrerie, O., Valentin, B., Delachapelle, H., Decocq, G. 2007. When Oskar meets Alice: does a lack of trade-off in $\mathrm{r} / \mathrm{K}$-strategies make Prunus serotina a successful invader of European forests? Forest Ecology and Management, 247, 120-130. 
Dassonville, N., Vanderhoeven, S., Vanparys, V., Hayez, M., Gruber, W., Meerts, P. 2008. Impacts of alien invasive plants on soil nutrients are correlated with initial site conditions in NW Europe. Oecologia, 157 (1), 131-140.

de Jong, M.D., Scheepens, P.C., Zadoks, J.C. 1990. Risk analysis for biological control: A Dutch case study in biocontrol of Prunus serotina by the fungus Chondrostereum purpureum. Plant Disease, 74, 189-194.

de Jong, M.D. 2000. The BioChon story: deployment of Chondrostereum purpureum to suppress stump sprouting in hardwoods. Mycologist, 14 (2), $58-62$.

Del Tredici, P. 2001. Sprouting in temperate trees: a morphological and ecological review. Botanical Review, 67 (2), 121-140.

Domański, S. 1988. Corticiaceae: AcanthobasidiumIrpicodon (in Polish). In: Short guide of the fungi. Basidiomycetes. Aphyllophorales vol. I, part 5 (ed.: S. Domański). Państwowe Wydawnictwo Naukowe, Warszawa - Kraków, Poland.

Domański, S. 1991. Basidiomycetes. Aphyllophorales. Stereaceae. Podoscyphaceae (in Polish). In: Flora of Poland. Fungi (Mycota), vol. 21 (eds.: J. Kochman, A. Skirgiełło). Państwowe Wydawnictwo Naukowe, Warszawa - Kraków, Poland.

Ginns, J. 1982. A monograph of the genus Coniophora (Aphyllophorales, Basidiomycetes). Opera Botanica, 61, 1-61.

Gosselin, L., Jobidon, R., Bernier, L. 1999. Biological control of stump sprouting of broadleaf species in rights-of-way with Chondrostereum purpureum: incidence of the disease on nontarget hosts. Biological Control, 16, 60-67.

Halarewicz, A. 2012. Ecological features and effects of the spread of black cherry Padus serotina (Ehrh.) Borkh. in selected forest phytocoenoses (in Polish with English summary). Monografie 152. Wydawnictwo Uniwersytetu Przyrodniczego we Wrocławiu, Poland.

Halarewicz, A., Pruchniewicz, D. 2015. Vegetation and environmental changes in a Scots pine forest invaded by Prunus serotina: What is the threat to terricolous bryophytes? European Journal of Forest Research, 134, 793-801.

IUSS Working Group WRB. 2015. World Reference Base for Soil Resources 2014, update 2015. Inter- national soil classification system for naming soils and creating legends for soil maps. World Soil Resources Reports No. 106, FAO, Rome, Italy.

Jobidon, R. 1997. Stump height effects on sprouting of mountain maple, paper birch and pin cherry - 10 year results. The Forestry Chronicle, 73 (5), 591-595.

Johansson, T. 1992a. Sprouting of 2-to 5-year-old birches Betula pubescens Ehrh., Betula pendula Roth. in relation to stump height and felling time. Forest Ecology and Management, 53 (1/4), 263-281.

Johansson, T. 1992b. Sprouting of 10-to 50-year-old Betula pubescens in relation to felling time. Forest Ecology and Management, 53 (1/4), 283-296.

Karasiński, D., Kujawa, A., Gierczyk, B., Ślusarczyk, T., Szczepkowski, A. 2015. Macrofungi of Kampinos National Park (in Polish with English summary). Kampinoski Park Narodowy, Izabelin, Poland.

Knudsen, H., Vesterholt, J. 2012. Funga Nordica, 2nd edition. Nordsvamp, Copenhagen, Denmark.

Konecka-Betley, K., Czępińska-Kamińska, D., Janowska, E., Okołowicz, M. 2002. Soil of strict and partial protection areas in the biosphere reserve „Kampinos Forest” (in Polish). Roczniki Gleboznawcze - Soil Science Annual, 53 (3/4), 5-21.

Krzysztofiak, L., Krzysztofiak, A. 2015 Elimination of alien plant species in Wigry National Park (in Polish). In: Elimination of invasive alien plant species - good and bad practices (eds.: L. Krzysztofiak, A. Krzysztofiak). Stowarzyszenie "Człowiek i Przyroda", Krzywe, Poland, 29-38.

Marquis, D.A. 1990. Black cherry Prunus serotina Ehrh. In: Silvics of forest trees in the United States (eds.: R.M. Burns, B.H. Honkala). Agriculture Handbook 654, vol. 2. Hardwoods, United States Department of Agriculture, Forest Service, Washington, DC, United States, 594-604.

Mycobank 2016. The MycoBank engine and related databases. http://www.mycobank.org. Accessed 1 November 2016.

Najberek, K., Solarz, W. 2011. Biological invasions in the Polish national and landscape parks (in Polish with English summary). In: Alien species in the fauna of Poland (eds.: Z. Głowaciński, H. Okarma, J. Pawłowski, W. Solarz). Instytut Ochrony Przyrody PAN, Kraków, Poland, 624-639. 
Namura-Ochalska, A., Borowa, B. 2015. The struggle against black cherry Padus serotina (Ehrh.) Borkh. in the forest division Rózin of the Kampinos National Park. Assessment of the effectiveness of selected methods (in Polish). In: Elimination of invasive alien plant species - good and bad practices (eds.: L. Krzysztofiak, A. Krzysztofiak). Stowarzyszenie "Człowiek i Przyroda", Krzywe, Poland, 57-74.

Otręba, A. Marciszewska, K, Janik, D. 2017. Is cut-stump and girdling an efficient method of black cherry Prunus serotina Ehrh. eradication? Folia Forestalia Polonica, Series A - Forestry, 59 (1), 14-24.

Polish Soil Science Society 2009. Classification of soil grains and mineral deposits - PSSS 2008 (in Polish). Roczniki Gleboznawcze - Soil Science Annual, 60 ( 2), 5-16.

Roy, V., Dubeau, D., Auger, I. 2010. Biological control of intolerant hardwood competition: Silvicultural efficacy of Chondrostereum purpureum and worker productivity in conifer plantations. Forest Ecology and Management, 259, 1571-1579.

Ryvarden, L., Melo, I. 2014. Poroid fungi of Europe. Synopsis Fungorum 31. Fungiflora, Oslo.

Scheepens, P.C., Hoogerbrugge, A. 1989. Control of Prunus serotina in forest with the endemic fungus Chondrostereum purpureum. Proceedings of the VII International Symposium on Biological Control of Weeds 6-11 March 1988 (ed.: E.S. Delfosse). Instituto Sperimentale del la Patologia Vegetale (MAF), Rome, Italy, 545-551.

Sierota, Z., Szczepkowski, A. 2014. Recognition of infectious diseases of forest trees (in Polish). CILP, Warszawa, Poland.

Starfinger, U., Kowarik, I., Rode, M., Schepker, H. 2003. From desirable ornamental plant to pest to accepted additional to the flora? - the perception of alien tree species through the centuries. Biological Invasions, 5, 323-335.

State Forests National Forest Holding. 2011. Forest Management Manual (in Polish). Part 2. Manual for distinguishing and mapping types of forest habitats and plant communities in the State Forests. CILP, Warszawa, Poland.

Tittenbrun, A., Radliński, B. 2015. Practices of eliminating alien invasive species in the Roztocze National Park (in Polish). In: Elimination of invasive alien plant species - good and bad practices (eds.: L. Krzysztofiak, A. Krzysztofiak). Stowarzyszenie "Człowiek i Przyroda", Krzywe, Poland, 49-54.

Tokarska-Guzik, B., Dajdok, Z., Zając, M., Zając, A., Urbisz, A., Danielewicz, W., Hołdyński, Cz. 2012. Alien plants in Poland with particular reference to invasive species (in Polish with English summary). The General Directorate for Environmental Protection, Warszawa, Poland.

Van den Meersschaut, D., Lust, N. 1997. Comparison of mechanical, biological and chemical methods for controlling black cherry (Prunus serotina) in Flanders (Belgium). Silva Gandavensis, 62, 90-109.

Vanhellemont, M. 2009. Present and future population dynamics of Prunus serotina in forests in its introduced range. Ph.D. thesis, Ghent University, Ghent, Belgium.

Van Reeuwijk, L.P. 2002. Procedures for soil analysis (6 $6^{\text {th }}$ ed.). Technical Paper, 9, ISRIC, Wageningen, The Netherland.

Vesk, P.A, Westoby, M. 2004. Sprouting ability across diverse disturbances and vegetation types worldwide. Journal of Ecology, 92 (2), 310-320.

Wojewoda, W. 2003. Checklist of Polish larger Basidiomycetes. In: Biodiversity of Poland, vol. 7 (ed.: Z. Mirek). W. Szafer Institute of Botany, Polish Academy of Sciences, Kraków, Poland.

Zespół klasyfikacji gleb leśnych. 2000. Classification of forest soils in Poland (in Polish). CILP, Warszawa, Poland.

Żółciak, A. 2005. Honey fungus (in Polish). CILP, Warszawa, Poland. 